\title{
Performance Assessment of Eco-friendly Brake composites reinforced organic dusts for Typical Characteristics
}

[Akıncıoglu, G., Uygur, I., Öktem H., Akıncıoglu, S.]

\begin{abstract}
Easy to supply and cheap materials like agricultural wastes are now appearing as a candidate materials in the brake pads development with commercial production and environmental consideration. In this study, asbestos-free automotive brake pads produced from walnut shell dusts (WAS) and wollastonite (WOS) with phenolic-resin binder was evaluated. Two nonasbestos friction material samples containing walnut shell dusts and wollastonite jute fibers from biomass as biodegradable components were prepared, also including several from natural resources, such as, basalt fibers, zircon, barite, and vermiculite. The physical, mechanical properties of the brake pad were studied.
\end{abstract}

\section{Keywords-Brake pads, organic dusts, water absorption}

\section{Introduction}

Organic friction materials are usually used in brakes of small planes, railroad vehicles, trucks and passenger cars. The developing vehicle sector requires a better investigation of the negative impact related to the release of potentially hazardous materials into the environment[1]. The brake pads generally consist of asbestos fibers embedded in polymeric matrix along with several other ingredients. The use of asbestos fibre is been dangerous due to its carcinogenic nature [2,3]. Because of harmful effect of asbestos for brake pads, much of the brake pad industry is moving away from asbestos brake pads [4,5] The friction materials normally contain multiple ingredients in varying composition, and they are classified as fibres, fillers, binders and property modifiers [6-9]. In recent years, the environmentally hazardous features of some components have been successfully applied in many automotive parts. Opposite to this friction composites, the non-asbestos organic friction composite mainly is being developed, which is partly closer to the environmentally friendly composites [10-16]. Besides environmental benefits of the natural fibers, their cost effectiveness is another focus when compared to the widely

Gülsah Akıncıoglu

Duzce University

Turkey

Ilyas Uygur

Duzce University

Turkey

Hasan Oktem

Kocaeli University

Turkey used Petroleum-coke and aramid fibers. The purpose of this study is to develop a new asbestos-free brake pad using agricultural waste (walnut shell dusts) and compare it with the other eco-friendly (wollastonite additive) pad. That's why the fabricated brake pads were examined for their physical (density, porosity) and mechanical properties (hardness, shear strength and compressibility).

\section{Material and Methods}

Walnut shell dusts were used during the current study as a friction adjuster material. Walnut dusts were first pulverized, sieved and dried in oven at $100{ }^{\circ} \mathrm{C}$ for about $1 \mathrm{~h}$. The granule size of the walnut dusts is approximately 250$400 \mu$. Wollastonite grain size is $125-250 \mu$. The type of walnut and its dusts are shown in Fig 1. The composition of eco-friendly friction samples is listed in Table 1. All raw materials were mixed with an industrial mixer for $10 \mathrm{~min}$, followed by molding and hot pressing at $180^{\circ} \mathrm{C}$ and $10 \mathrm{MPa}$ for $6 \mathrm{~min}$ in a hydraulic press. The pressed brake pads were freely held within an electric furnace which has aircirculation in temperature from $300{ }^{\circ} \mathrm{C}$ to $150{ }^{\circ} \mathrm{C}$ during 10 hours. After post-curing, the brake pads were finished by polishing them using polisher-grinder with various grinding paper of various sizes to obtain the final products.

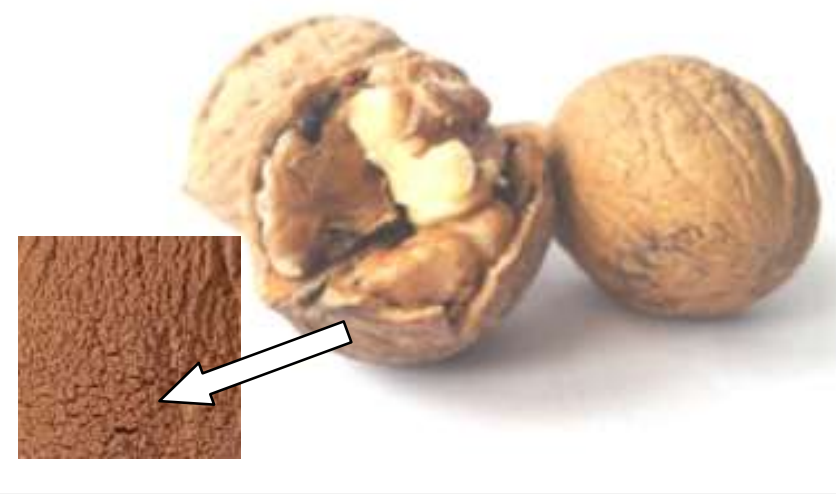

Figure 1. The walnut dusts

Water and oil soak test were applied to the pad samples. The brake pads were put in the water and oil for 24 hours. The weights, hardness, thickness of all samples were measured before and after this process as shown Fig.2. The true density of the brake pad materials was determined by weighing the samples on a digital precision balance and measuring their volume by liquid displacement method (Fig. $3)$.

TABLE I.THE COMPOSITION OF ECO-FRIENDLY PAD SAMPLES 
Proc. of The Sixth Intl. Conf. On Advances in Applied Science and Environmental Technology - ASET 2017 Copyright (C) Institute of Research Engineers and Doctors, USA .All rights reserved.

ISBN: 978-1-63248-119-1 doi: 10.15224/ 978-1-63248-119-1-37

\begin{tabular}{cccc}
\hline No & Dust Materials & $\begin{array}{c}\text { (Compositions) } \\
\text { (wt. \%) }\end{array}$ & $\begin{array}{l}\text { Dust } \\
\text { mesh } \\
\text { size } \\
(\boldsymbol{\mu m})\end{array}$ \\
\hline $\mathbf{1}$ & Steel fiber & $15-20$ & 125 \\
$\mathbf{2}$ & Rock wool & $3-6$ & $6-10$ \\
$\mathbf{3}$ & Kevlar pulp & $0.5-2$ & 12 \\
$\mathbf{4}$ & Graphite & $5-7$ & 45 \\
$\mathbf{5}$ & Phenolic Resin & $6-8$ & 63 \\
$\mathbf{6}$ & Vermiculite & $6-8$ & 500 \\
$\mathbf{7}$ & Brass & $4-6$ & $50-100$ \\
$\mathbf{8}$ & Calcium hydroxide & $7-9$ & 40 \\
$\mathbf{9}$ & Zirconium Silicate & $3-5$ & 10 \\
$\mathbf{1 0}$ & Metal Sulfide & $0.5-1$ & 45 \\
$\mathbf{1 1}$ & Iron oxide (Fe $\left.\mathrm{O}_{3}\right)$ & $1-3$ & 0.2 \\
$\mathbf{1 2}$ & Rubber scrap & $4-6$ & 50 \\
$\mathbf{1 3}$ & Barytes & $6-8$ & 55 \\
$\mathbf{1 4}$ & Rubber (NBR) & $2-4$ & 50 \\
$\mathbf{1 5}$ & Petrocoke & $3-5$ & 125 \\
$\mathbf{1 6}$ & Chalcopyrite(CuFeS) & $4-7$ & 50 \\
$\mathbf{1 7}$ & Mica+silica & $4-5$ & $50-100$ \\
$\mathbf{1 8}$ & Walnut dusts (WAS) & 7 & $250-400$ \\
$\mathbf{1 9}$ & Wollastonite (WOS) & 4.5 & $125-200$ \\
\hline
\end{tabular}

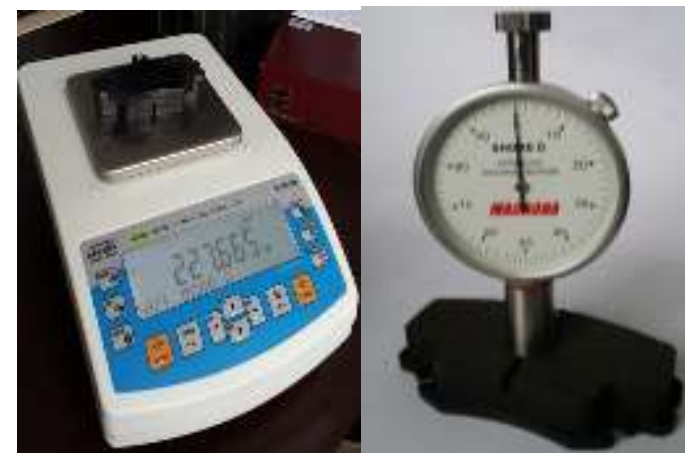

(a) Weight

(b) Hardness

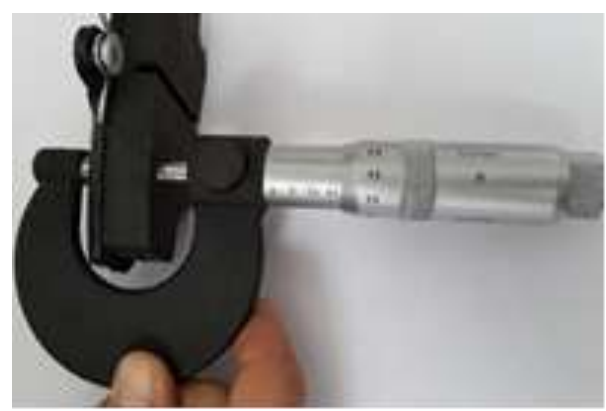

(c) Thickness

Figure 2. The measurement of the friction composites

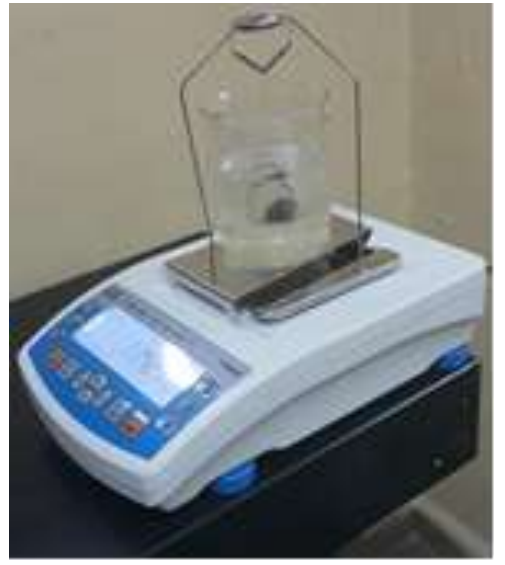

Figure 3 . The density measurement of the friction composites

The compression test was conducted on a special design (Kale Balata Pad factory) during 3 seconds, strength testing machine of 160 bar capacity. Shear strength for the qualification of brake pad integrity along the force was measured on a new design testing machine from Kale Balata Factory. The test were applied according to ISO 6310 [17] and 6312 standards [18].

\section{Result and Discussions}

\section{a. Physical, chemical and mechanical properties of the friction composites}

The results of physical, chemical and mechanical properties of the brake friction composites are shown in Table 2.

TABLE I. THE TEST RESULTS

\begin{tabular}{lll}
\hline Typical characteristics & WAS & WOS \\
\hline Hardness (Shore D) & 90 & 89 \\
Hardness (After water absorption) & 84 & 86 \\
Water absorption $(\%)$ & 0.43 & 0.37 \\
Density $\left(\mathrm{g} / \mathrm{cm}^{3}\right)$ & 2.232 & 2.028 \\
Compressibility $(\mu)$ & 187 & 146 \\
Shearing test $(\mathrm{N})$ & 773.4 & 773.1 \\
\hline
\end{tabular}

The hardness values were obtained as 90 and 89 Shore D for walnut and wollastonite samples, respectively. After the 24 hours water absorption, the hardness values for both friction samples were decreased. As can be understood from this, the brake composites absorb water into its body [3]. It is also seen from this, wood based WAS more tendency to absorbtion compared nonorganic WOS material. That is why reason for the walnut dusts absorbs to water more than wollastonite dusts. On the other hand, the density of the WAS samples are higher than that of the WOS samples. The water absorption values for these pads were compared with other materials from some researches indicated an acceptable result with the findings of other researchers [19]. In addition, density values were obtained are within the recommended results for brake pad application [20]. Shear strength has been obtained approximately the same values for two samples which are $773 \mathrm{~N}$. The results are in the 
Proc. of The Sixth Intl. Conf. On Advances in Applied Science and Environmental Technology - ASET 2017 Copyright (C) Institute of Research Engineers and Doctors, USA .All rights reserved.

ISBN: 978-1-63248-119-1 doi: 10.15224/ 978-1-63248-119-1-37

acceptable value range according to ISO 6312 standard. Compressibility test results are for the WAS sample $187 \mu$ and for the WOS sample $146 \mu$. The high value means the hardness is low. If the pads compress more, its hardness is low. The compressibility of samples with walnut dust is higher than that samples with wollastonite dust whereas the hardness of WAS sample is lower than that of WOS sample.

The microstructure of brake friction composites as shown in Fig.4 is observed using a digital metallurgical microscope (50Xmagnification). From this, it can be seen that the friction dusts consisting brake friction composites have distributed as homogeneous within the matrix. As can also be seen in general from this figures that the gray regions are matrix (fillers and binders), some of bright regions likes needle are reinforcement (steel fiber) and the others are friction modifiers and abrasives. Also, there are micro-voids on the surfaces of almost all samples. Micro-voids consist of the metallic particles and organic dusts.
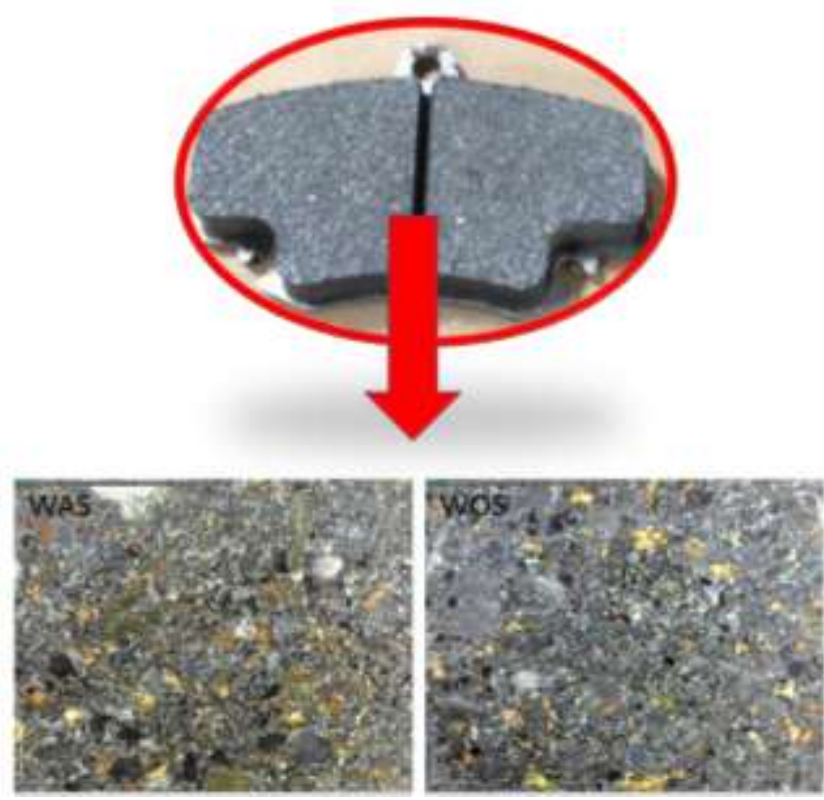

Figure 4. Optical micrographs of the brake friction composites

From the results and discussion in this work the following conclusions can be made:

- Walnut shell dusts can be used successfully brake friction composites manufacturing, using a compressive molding.

- It can be seen from results that there is direct relation between the brake friction samples hardness and water absorption.

- The WAS samples has a density value bigger than the WOS samples.

- The important change between the values of shearing strength on the samples of the WOS and WAS is not observed.

- Compressibility test results are for the WAS sample 187 $\mu$ and for the WOS sample $146 \mu$ because WAS samples are compress more than the WOS samples.
- Finally, the whole results obtained from brake friction composites are within the acceptable range according to international standards.

\section{Abbreviations and Acronyms}

This study is supported by Scientific Research Project Unit of Duzce University (DÜBAP-2015/72).

\section{References}

[1] K. Malachova, J. Kukutschova, Z. Rybkova, H. Sezimova, D. Placha, K. Cabanova, et al., "Toxicity and mutagenicity of lowmetallic automotive brake pad materials," Ecotoxicology and Environmental Safety, vol. 131, pp. 37-44, 9// 2016.

[2] U. D. Idris, V. S. Aigbodion, I. J. Abubakar, and C. I. Nwoye, "Eco-friendly asbestos free brake-pad: Using banana peels," Journal of King Saud University - Engineering Sciences, vol. 27, pp. 185-192, 7// 2015.

[3] T. Singh, A. Patnaik, and R. Chauhan, "Optimization of tribological properties of cement kiln dust-filled brake pad using grey relation analysis," Materials \& Design, vol. 89, pp. 1335$1342,1 / 5 / 2016$

[4] I. Dagwa and A. Ibhadode, "Design and manufacture of automobile disk brake pad test rig," Nigerian Journal of Engineering Research and Development, vol. 4, pp. 15-24, 2005.

[5] M. C. Lagel, L. Hai, A. Pizzi, M. C. Basso, L. Delmotte, S. Abdalla, et al., "Automotive brake pads made with a bioresin matrix," Industrial Crops and Products, vol. 85, pp. 372-381, 7// 2016.

T. Singh and A. Patnaik, "Performance assessment of lapinusaramid based brake pad hybrid phenolic composites in friction braking," Archives of Civil and Mechanical Engineering, vol. 15, pp. 151-161, 1// 2015.

G. Nicholson, Facts about Friction: A Friction Material Manual Almost All You Need to Know about Manufacturing; 100 Years of Brake Linings \& Clutch Facings: P\&W Price Enterprises, Incorporated, 1995.

W. Österle and A. Dmitriev, "Functionality of conventional brake friction materials-perceptions from findings observed at different length scales," Wear, vol. 271, pp. 2198-2207, 2011.

J. Bijwe, "Composites as friction materials: Recent developments in non-asbestos fiber reinforced friction materialsa review," Polymer composites, vol. 18, pp. 378-396, 1997.

S. Qi, Z. Fu, R. Yun, S. Jiang, X. Zheng, Y. Lu, et al., "Effects of walnut shells on friction and wear performance of ecofriendly brake friction composites," Proceedings of the Institution of Mechanical Engineers, Part J: Journal of Engineering Tribology, vol. 228, pp. 511-520, 2014.

Y. Ma, S. Shen, J. Tong, W. Ye, Y. Yang, and J. Zhou, "Effects of bamboo fibers on friction performance of friction materials," Journal of Thermoplastic Composite Materials, vol. 26, pp. 845$859,2013$.

S. Hashmi, U. Dwivedi, and N. Chand, "Graphite modified cotton fibre reinforced polyester composites under sliding wear conditions," Wear, vol. 262, pp. 1426-1432, 2007.

S. A. Bahari, K. H. Isa, M. A. Kassim, Z. Mohamed, and E. A. Othman, "Investigation on hardness and impact resistance of automotive brake pad composed with rice husk dust," in $2 N D$ ASEAN-APCTP WORKSHOP ON ADVANCED MATERIALS SCIENCE AND NANOTECHNOLOGY:(AMSN 2010), 2012, pp. 155-161

M. Gürü, S. Tekeli, and İ. Bilici, "Manufacturing of ureaformaldehyde-based composite particleboard from almond shell," Materials \& Design, vol. 27, pp. 1148-1151, // 2006.

M. Sutikno, P. Marwoto, and S. Rustad, "The mechanical properties of carbonized coconut char powder-based friction materials," Carbon, vol. 48, pp. 3616-3620, 10// 2010.

H. Öktem, İ. Uygur, G. Akincioğlu, D. Kir, And H. Karakaş, "Evaluation Of Non-Asbestos High Performance Brake Pads Produced With Organic Dusts."2015 
Proc. of The Sixth Intl. Conf. On Advances in Applied Science and Environmental Technology - ASET 2017 Copyright (C) Institute of Research Engineers and Doctors, USA .All rights reserved.

ISBN: 978-1-63248-119-1 doi: 10.15224/ 978-1-63248-119-1-37

[17]

M. Kaido and Y. Sasaki, "Harmonization Activities on ISO and JIS Standards (Compressibility) for Brake Linings in Japan," SAE Technical Paper 0148-7191, 2001.

[18] R. Basch, C. Agudelo, T. Millsap, and D. Carter, "Evaluation of SAE J840 Lining Shear Test Procedure," 2006.

[19] D. S. Yawas, S. Y. Aku, and S. G. Amaren, "Morphology and properties of periwinkle shell asbestos-free brake pad," Journal of King Saud University - Engineering Sciences, vol. 28, pp. 103-109, 1// 2016.

[20] N. Hooton, "Metal-ceramic composites in high-energy friction applications(Sliding friction and wear properties of metal ceramic composites applied to aircraft brakes)," Bendix Technical Journal, vol. 2, pp. 55-61, 1969.

About Author (s):

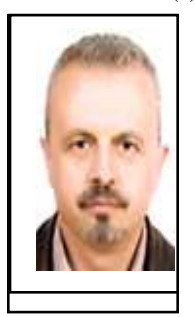

Prof. Dr. İlyas Uygur, born in Turkey, Balıkesir. He is currently Dean of Engineering Faculty in Duzce. His main are is Materails Science and Engineering.

Typical research areas: Composite materials, fatigue, welding, cryogenic treatment, and corrosion 